\title{
Increase of the number of broods of Fall Armyworm (Spodoptera frugiperda) as an indicator of global warming
}

\section{Aumento del número de generaciones de gusano cogollero (Spodoptera frugiperda) como indicador del calentamiento global}

\author{
Nadiezhda Ramírez-Cabral ${ }^{*}$; Guillermo Medina-García ${ }^{1}$; Lalit Kumar $^{2}$ \\ ${ }^{1}$ Instituto Nacional de Investigaciones Forestales, Agrícolas y Pecuarias. INIFAP. Campo Experimental \\ Zacatecas, km 24.5 Carretera Zacatecas-Fresnillo. C.P. 98500. Zacatecas, México. \\ ${ }^{2}$ University of New England, Ecosystem Management, School of Environmental and Rural Science, \\ Armidale, NSW, Australia. \\ *Corresponding author: ramirez.nadiezhda@inifap.gob.mx
}

Abstract

Keywords: Maize, climate change implications, increase in generations, growing degree days.

Palabras clave: Maíz, implicaciones del cambio climático, aumento en generaciones, grados días de desarrollo.
Y leld losses are closely related to the increased pests on crops. Higher temperatures can lead to an earlier establishment, shorter life cycles, more generations and spread in a geographic range. Corn is an important economic crop worldwide. One of its main pests, Spodoptera frugiperda (fall armyworm, FAW) is causing losses of millions of dollars. Maps of climatic scenarios show an increase in the number of FAW generations for the study area. While currently three and four generations are the most common, by 2060 four and five generations can occur over most of the state area. In some areas, seven generations can occur within a season; currently, seven generations do not occur in the state but six generations can occur in very small areas. These results show that more days with warm temperatures in a breeding season can lead to a decrease in the FAW life cycle duration, enabling more broods per season. This increase can generate more pressure in agricultural areas with negative economic and social impacts on the corn supply in the future. The results of this modelling could be used to perform mitigation and adaptation policies to guarantee food security under a changing global climate.

\section{Resumen}

$\mathrm{L}$ as pérdidas en los rendimientos están estrechamente relacionadas con el aumento de las plagas en los cultivos. Las temperaturas más elevadas pueden dar lugar a un Lestablecimiento más temprano, ciclos de vida más cortos, más generaciones y mayor dispersión en un área geográfica. El maíz es un cultivo económico importante en todo el mundo. Una de sus principales plagas, Spodoptera frugiperda (gusano cogollero) está causando pérdidas de millones de dólares. Los mapas de escenarios climáticos muestran un aumento en el número de generaciones de gusano cogollero para el área de estudio. Mientras que actualmente tres y cuatro generaciones es lo más común, para 2060 cuatro y cinco generaciones pueden presentarse en la mayor parte del territorio estatal. En la actualidad, el mayor número de generaciones es de seis en pequeñas áreas. En un futuro se predicen áreas con siete generaciones de cogollero, lo cual no ocurre actualmente. Estos resultados muestran que un mayor número días con temperaturas cálidas en una temporada de cría pueden llevar a una disminución de la duración del ciclo de vida del gusano cogollero, permitiendo así más generaciones por temporada. Este aumento puede generar más presión en las zonas agrícolas con impactos económicos y sociales negativos en la oferta de maíz en el futuro. Los resultados de esta modelación podrían utilizarse para llevar a cabo políticas de mitigación y adaptación para garantizar la seguridad alimentaria en un clima mundial cambiante.

Please cite this article as follows (APA 6): Ramírez-Cabral, N., Medina-García, G. \&

Kumar, L. (2020). Increase of the number of broods of Fall Armyworm (Spodoptera

frugiperda) as an indicator of global warming. Revista Chapingo Serie Zonas Áridas, 19(1), 1-16.

doi: 10.5154/r.rchsza.2020.11.01 


\section{Introduction}

Changes on climate have been on-going for thousands of years in a natural way. However, human activity has been an important contributor to the increase in global warming since the middle of the 1950s. An increase of $0.6^{\circ} \mathrm{C}$ in the global average temperature has occurred over the last 100 years (IPCC, 2014). Predicted changes in temperature (an average rate of $0.13{ }^{\circ} \mathrm{C}$ per decade over the last 50 years), precipitation and extreme events are some of the consequences of this new variability. The changes will impact on ecosystem health, availability of water resources, food security, animal health and welfare, agriculture and many other aspects (IPCC, 2014).

Agricultural productivity, as well as plagues and diseases can be affected in both positive and negative ways by climate factors such as temperature, precipitation, humidity, solar radiation and wind. Among these, temperature is the most important due to its great influence on ectothermal organisms such as plants and insects (Fuhrer, 2003, Diffenbaugh, N. S., Krupke, C. H., White, M. A., \& Alexander, C. E., 2008, Medina, G. G., Ruíz, C. J. A., Ramírez, L. M. R., \& Díaz, P. G., 2011.). For example, the increase in temperature can allow many crops to mature in a shorter period of time due to a faster accumulation of heat necessary for their development. Notwithstanding, a serious drawback is the potential increase in the number and diversity of pests along warmer regions with high and medium altitudes. Climate change could affect agricultural yield both directly and indirectly. High levels of $\mathrm{CO}_{2}$ may cause increasing yields but may also make longer growing seasons for different crops. Additionally, changes in the spatial distribution of land area under crop production may occur under climate change, with some regions becoming favourable for some crops while unfavourable for others (Parry, M., Porter, J., \& Carter, T., 1990). Due to these impacts, changing climate patterns could be altering food supply and demand relationship worldwide. Some regions may have yield losses while others may have benefits from improved production (Rosenzweig, C., Iglesias, A., Yang, X., Epstein, P. R., \& Chivian, E., 2001).

Yield losses are closely related to the increased pest impacts on crops. Effects of climate change on insects might be direct such as affecting life cycles, or indirect such as affecting hosts, competitors and/or predators (Cannon, 1998, Patterson, D., Westbrook, J., Joyce, R., Lingren, P., \& Rogasik, J., 1999, Bale et al., 2002). Environmental signals are synchronized for the start and end of the growth and development of insects. Insects processes may be affected by high temperatures due to their effects on geographic ranges, diapause, growth rates, migration, host preference,

\section{Introducción}

Los cambios en el clima han estado en curso durante miles de años de manera natural. Sin embargo, la actividad humana ha contribuido en gran medida al aumento del calentamiento global desde mediados de la década de 1950 . Un incremento de $0.6{ }^{\circ} \mathrm{C}$ en la temperatura media global se ha producido en los últimos 100 años (IPCC, 2014). Los cambios pronosticados en la temperatura (un promedio de $0.13{ }^{\circ} \mathrm{C}$ por década en los últimos 50 años), la precipitación y los eventos extremos son algunas de las consecuencias de esta nueva variabilidad. Los cambios afectarán la salud del ecosistema, la disponibilidad de recursos hídricos, la seguridad alimentaria, la salud y el bienestar de los animales, la agricultura y muchos otros aspectos (IPCC, 2014).

La productividad agrícola, así como las plagas y enfermedades, pueden verse afectadas tanto positivacomo negativamente por elementos del clima como la temperatura, la precipitación, la humedad, la radiación solar y el viento. Entre estos, la temperatura es la más importante debido a su gran influencia en los organismos ectotermos como plantas e insectos (Fuhrer, 2003, Diffenbaugh, N. S., Krupke, C. H., White, M. A., \& Alexander, C. E., 2008, Medina, G. G., Ruíz, C. J. A., Ramírez, L. M. R., \& Díaz, P. G., 2011). Por ejemplo, el aumento de la temperatura puede permitir que muchos cultivos maduren en un plazo más corto debido a una acumulación más rápida del calor necesario para su desarrollo. No obstante, un grave inconveniente es el posible aumento en número y diversidad de plagas a lo largo de las regiones más cálidas de altitudes alta y media. El cambio climático podría afectar el rendimiento agrícola tanto directa- como indirectamente. Niveles altos de $\mathrm{CO}_{2}$ pueden originar rendimientos crecientes, pero también pueden prolongar las temporadas de crecimiento de diversos cultivos. Además, en el marco del cambio climático pueden producirse cambios en la distribución espacial de las tierras dedicadas a la producción de cultivos, de modo que algunas regiones se vuelven favorables para algunos cultivos mientras que en otras se vuelven desfavorables para otros (Parry, M., Porter, J., \& Carter, T., 1990). Debido a estos impactos, los patrones del cambio climático podrían estar alterando la relación entre oferta y demanda de alimentos a nivel global. Algunas regiones pueden tener pérdidas de rendimiento mientras que otras pueden tener beneficios por una producción mejorada (Rosenzweig, C., Iglesias, A., Yang, X., Epstein, P. R., \& Chivian, E., 2001).

Las pérdidas de rendimiento están estrechamente relacionadas con el aumento en los impactos por plagas en los cultivos. Los efectos del cambio climático sobre los insectos pueden ser directos, como los que 
abundance, synchronization, survival, mortality and number of broods per year. Number of broods per year is defined as voltinism. Diapause is obligatory on univoltine insects (one generation per year) contrary to multivoltine (two or more generations per year) where diapause occurs in response to an environmental situation and is facultative (Tauber, M. J., Tauber, C. A., \& Shinzo, M., 1986, Saunders, 2002). Warmer temperatures could improve insect development; however, temperature exceeding insect upper thresholds might affect fecundity and increase mortality. Evolutionarily, insects can adapt to changing environment (Patterson et al., 1999; Bale et al., 2002).

High temperatures can lead to an earlier establishment of pests. Multivoltine insects might have more generations within a season and migratory insects could be established and developed in new regions, thus pest density, crop damage and expanding ranges could be increasing in regions at high altitudes and latitudes. Insects with no diapause and fast growing are frequently multivoltine, like aphids and members of the Lepidoptera order, such as butterflies and moths. With enough food and good weather, insects can continue their reproduction cycle for as many generations as possible. The number of generations within a season can depend on temperature and food availability. While higher temperatures favour abundance of insects, the quality of the host and the natural enemies also plays key roles (Parry et al., 1990, Pollard, E., Moss, D., \& Yates, T., 1995, Bale et al., 2002). Insects have overcome climate change challenges, becoming as the most successful group of living-organisms on Earth. The success of insects is a result of their high adaptability to a changing environment (Bale et al., 2002; Bradshaw \& Holzapfel, 2006). Climate change effects on pests are difficult to predict due to the complex interactions among insects, hosts and predators. Weather tolerance depends on the stage of the insect; younger instars are more susceptible than older ones. There are fossil evidences that climate is the main factor that regulates the development and distribution of insects. Insect and plant distributions are highly correlated (Bale et al., 2002). Researchers have reported that a temperature increment of $1{ }^{\circ} \mathrm{C}$ may allow insect movements of up to $200 \mathrm{~km}$ (Watt, A., Ward, L., \& Eversham, B., 1990). Species distribution would depend on the ability of the insect to disperse, the natural and artificial barriers and the suitability of the new habitat. Borders may not be a constraint to migrant insects and warmer winters could change migrants status to become resident species (Coope, 1970; Watt et al., 1990).

Corn (Zea mays L.) is an important global staple crop. It is one of the three main cereals worldwide (wheat, sorghum, corn) due its grains contain a high amount of nutrients and vitamins ( Brown, W. L., Zuber, M. S., afectan a los ciclos vitales, o indirectos, que afectan a los hospederos, competidores o depredadores (Cannon, 1998, Patterson, D., Westbrook, J., Joyce, R., Lingren, P., \& Rogasik, J., 1999, Bale et al., 2002). Las señales ambientales están sincronizadas para el comienzo y el final del crecimiento y desarrollo de los insectos. Los procesos de los insectos pueden verse afectados por las temperaturas altas debido a sus efectos sobre las áreas geográficas, la diapausa, las tasas de crecimiento, la migración, la preferencia de los hospederos, la abundancia, la sincronización, la supervivencia, la mortalidad y el número de generaciones por año. El número de generaciones por año se define como voltinismo. La diapausa es obligatoria en los insectos univoltinos (una generación por año), a diferencia de los multivoltinos (dos o más generaciones por año), en los que la diapausa se produce en respuesta a una situación medioambiental y es facultativa (Tauber, M. J., Tauber, C. A., \& Shinzo, M., 1986, Saunders, 2002). Las temperaturas más cálidas podrían mejorar el desarrollo de los insectos; sin embargo, temperaturas que excedan los umbrales superiores de los insectos podrían afectar la fecundidad y aumentar la mortalidad. Evolutivamente, los insectos pueden adaptarse a un entorno cambiante (Patterson et al., 1999, Bale et al., 2002).

Las temperaturas altas pueden conducir a un establecimiento más temprano de las plagas. Los insectos multivoltinos podrían tener más generaciones en una temporada y los insectos migratorios podrían establecerse y desarrollarse en nuevas regiones, por lo que la densidad de plagas, los daños a los cultivos y las áreas de distribución podrían aumentar en las regiones de altas altitudes y latitudes. Los insectos sin diapausa y de crecimiento rápido suelen ser multivoltinos, como los áfidos y los miembros del orden Lepidoptera, tales como mariposas y polillas. Con suficiente alimento y buen clima, los insectos pueden continuar su ciclo de reproducción durante tantas generaciones como sea posible. El número de generaciones dentro de una temporada puede depender de la temperatura y la disponibilidad de alimento. Si bien las temperaturas más altas favorecen la abundancia de insectos, la calidad del hospedero y de los enemigos naturales también desempeñan papeles fundamentales (Parry et al., 1990, Pollard, E., Moss, D., \& Yates, T., 1995, Bale et al., 2002). Los insectos han superado los desafíos del cambio climático, convirtiéndose en el grupo de organismos vivos más exitoso del planeta. El logro de los insectos es resultado de su gran adaptabilidad a un entorno cambiante (Bale et al., 2002, Bradshaw \& Holzapfel, 2006). Los efectos del cambio climático sobre las plagas son difíciles de predecir debido a las complejas interacciones entre los insectos, los hospederos y los depredadores. La tolerancia al clima depende de la etapa del insecto; los estadios más 
Darrah, L. L., \& Glover, D. V., 1985, FAO, 1992, Suárez, R. F., Chávez, L. A. M., \& Mariscal, A. G., 2013). Corn production has been quadrupled in the last 50 years to $800 \mathrm{MT}$; this is mainly related to the increase in population in developing countries (FAOSTAT, 2014). Corn is also used in biodiesel production, then demand for this crop has been increasing (Baker \& Zahniser, 2006). In Mexico, corn plays an important role, not only as a staple crop but also has symbolic and religious values, creating part of the national culture (Suárez et al., 2013).

To satisfy the growing demand of corn it is necessary to be aware of how pests can affect this crop under different climatic scenarios. Corn can be damaged by 90 different insect pests; some of them are considered critical and have an occurrence every season at least (Valdivieso \& Núñez, 1984, O’Day, M. H., Becker, A., Keaster, A. J., Kabrick, L. R., \& Steffey, K. L., 1998, Diffenbaugh et al., 2008). In the corn growing regions of Mexico, an average temperature increase of $2{ }^{\circ} \mathrm{C}$ (2051-2060) can have an important impact on pests (Ruiz et al., 2013). One of the main pests in corn is the fall armyworm (Spodoptera frugiperda (J. E. Smith)). FAW, acronym of $S$. frugiperda. It is a polyphagous insect with 186 different hosts; more than $50 \%$ of the hosts are located in North and Central America. The most common hosts are corn, sorghum, peanut, grasses, sugarcane and rice (Casmazu et al., 2010). Polyphagous insects are flexible specimens living in a wide range of altitudes and latitudes. FAW might adapt better to weather changes due to their phenotypic and genotypic plasticity. The FAW specimens may feed even on hosts of low quality when the main host are not available, adapting with the changes in their environment (Sparks, 1979; Randall, 1986; Bale et al., 2002). FAW is an important agricultural pest of the Western Hemisphere. There is evidence of several outbreaks in the United States of America (1975-1977) with estimated losses of millions of dollars (Bale et al., 2002). In some regions of Mexico, FAW is the major pest in maize and affects crop output every year (Hernández, J. L. M., López, E. C. B., Garza, E. G., \& Mayek, N. P., 2008, García \& Tarango, 2009, Valdez, T. J. B., Soto, L. F., Osuna, E. T., \& Báez, S. M. A., 2012). Females oviposit hundreds of eggs in clusters protected by scales, generally on the lower surface of leaves. Once the larvae hatch they start to feed to pass through six instars. The last instar drops to the soil, pupates and emerges like an adult. The life cycle may take around 38 to 62 days to complete (Vickery, 1929; Sparks, 1979).

Numerous numerical models have been used to know climate distribution of insects (Yamamura \& Kiritani, 1998, Turner, R., Song, Y. H., \& Uhm, K. B., 1999, Crozier \& Dwyer, 2006, Fraisse et al., 2006, Morin \& Thuiller, 2009, Maes et al., 2010). However, there have been few jóvenes son más susceptibles que los más viejos. Existen evidencias fósiles de que el clima es el principal factor que regula el desarrollo y la distribución de los insectos. La distribución de insectos y plantas está altamente correlacionada (Bale et al., 2002). Los investigadores han informado que, un incremento de la temperatura de $1{ }^{\circ} \mathrm{C}$ puede permitir movimientos de insectos de hasta $200 \mathrm{~km}$ (Watt, A., Ward, L., \& Eversham, B., 1990). La distribución de las especies dependería de la capacidad de dispersión del insecto, de las barreras naturales y artificiales, y de la idoneidad del nuevo hábitat. Es posible que las fronteras no sean una limitación para los insectos migratorios, y los inviernos más cálidos podrían cambiar las condiciones de migrantes para que se conviertan en especies residentes (Coope, 1970; Watt et al., 1990).

El maíz (Zea mays L.) es un importante cultivo básico a nivel global. Es uno de los tres principales cereales del mundo (trigo, sorgo, maíz) debido a que sus granos contienen una gran cantidad de nutrientes y vitaminas (Brown, W. L., Zuber, M. S., Darrah, L. L., \& Glover, D. V., 1985, FAO, 1992, Suárez, R. F., Chávez, L. A. M., \& Mariscal, A. G., 2013). La producción de maíz se ha cuadruplicado en los últimos 50 años hasta alcanzar las 800 MT; esto se relaciona principalmente con el aumento de la población en los países en desarrollo (FAOSTAT, 2014). El maíz también se utiliza en la producción de biodiésel, por lo que la demanda de este cultivo ha ido en aumento (Baker \& Zahniser, 2006). En México, el maíz desempeña un papel importante, no solamente como cultivo básico, sino que también tiene valores simbólicos y religiosos constituyen parte de la cultura nacional (Suárez et al., 2013).

Para satisfacer la creciente demanda de maíz es necesario comprender cómo pueden afectar las plagas a este cultivo bajo diversos escenarios climáticos. El maíz puede ser dañado por 90 plagas de insectos diferentes; algunas de ellas se consideran críticas y se presentan por lo menos cada temporada (Valdivieso \& Núñez, 1984, O’Day, M. H., Becker, A., Keaster, A. J., Kabrick, L. R., \& Steffey, K. L., 1998, Diffenbaugh et al. 2008). El cultivo de maíz en las regiones mexicanas, un aumento medio de $2{ }^{\circ} \mathrm{C}$ en la temperatura (20512060) puede tener un impacto importante en las plagas (Ruiz et al., 2013). Una de las principales plagas del maíz es el gusano cogollero (Spodoptera frugiperda (J. E. Smith). El cogollero es un insecto polífago con 186 hospederos diferentes; más del 50 \% de los hospederos se encuentran en América del Norte y Centroamérica. Los hospederos más comunes son el maíz, el sorgo, el cacahuete, las gramíneas, la caña de azúcar y el arroz (Casmazu, 2010). Los insectos polífagos son especímenes flexibles que viven en una amplia gama de altitudes y latitudes. El gusano cogollero podría adaptarse mejor a los cambios climáticos debido a su plasticidad 
attempts to study weather change impacts on pests at local levels in Mexican agricultural areas and crops. The main issues of weather change can have impact on pests; for instance, increases of generations (number of broods) per season and the spread in geographic ranges (Patterson et al., 1999). This knowledge shall allow farmers to perform some adaptation measures, such as use of technical innovations, and new varieties and management practices to overcome weather change impacts (Parry et al., 1990). This investigation focuses on how warmer temperatures are likely to affect the life cycle of FAW. More specifically, we investigate how changing temperature regimes can impact on the number of broods per season. We hypothesize that with a larger number of days having warmer temperatures in the breeding season there is an enhanced opportunity for more broods per season. We also hypothesize that with a larger part of a day having warmer temperatures in a breeding season the life cycles will be shorter, enabling more broods per season as well as a higher abundance of pests. We also model regions in Mexico that might become climatically suitable for FAW and overlay this with corn growing areas to study potential impacts on output. The results of this investigation could help to better understand how climate changes can impact on maize pests such as FAW are likely to affect corn and to implement mitigation and adaptation policies to guarantee corn production and consequently food security.

\section{Materials and methods}

\section{Study area}

The modelling experiments were carried out for Zacatecas, Mexico. The state of Zacatecas is located in the center-north of Mexico in the Central Plateau of the country. It covers an area of $75040 \mathrm{~km}^{2}$, with an average altitude of 2230 masl. Its average annual temperature is $16{ }^{\circ} \mathrm{C}$ and yearly precipitation of $510 \mathrm{~mm}$. Its territory is located between $25^{\circ} 09^{\prime}$ to $21^{\circ}$ $04^{\prime}$ north latitude, and between $100^{\circ} 49^{\prime}$ to $104^{\circ} 19^{\prime}$ west longitude (Figure 1).

\section{Retrospective analysis}

A retrospective analysis was conducted to determine the behavior of the accumulation of growing degree days (GDD) considering data from five weather stations in the Zacatecas state. The stations were Colonia Gonzáles Ortega (1973-2009), El Chique (1973-2009), Tlaltenango (1973-2009), Teúl de Gonzáles Ortega (19732007) and Campo Experimental Zacatecas, CEZAC (1973-2010). Data from two institutions were used. Climate data for 1973 to 2002 was obtained from the Comisión Nacional del Agua (CNA, i.e. National Water Commission in English) and for 2003 to 2009 from fenotípica y genotípica. Los especímenes de cogollero pueden alimentarse, incluso, de hospederos de baja calidad cuando no se dispone del hospedero principal, adaptándose a los cambios de su entorno (Sparks, 1979, Randall, 1986, Bale et al., 2002). El cogollero es una importante plaga agrícola del hemisferio occidental. Existen evidencias de varios brotes en los Estados Unidos de América (1975-1977) con pérdidas estimadas en millones de dólares (Bale et al., 2002). En algunas regiones de México, el cogollero es la principal plaga del maíz y afecta la producción todos los años (Hernández, J. L. M., López, E. C. B., Garza, E. G., \& Mayek, N. P., 2008, García \& Tarango, 2009, Valdez, T. J. B., Soto, L. F., Osuna, E. T., \& Báez, S. M. A., 2012). Las hembras depositan cientos de huevos en racimos protegidos por escamas, generalmente en la superficie inferior de las hojas. Una vez que las larvas eclosionan, comienzan a alimentarse para pasar por seis estadios. El último estadio cae al suelo, se transforma en pupa y emerge como adulto. El ciclo de vida puede tardar entre 38 y 62 días en completarse (Vickery, 1929, Sparks, 1979).

Se han utilizado numerosos modelos numéricos para conocer la distribución climática de los insectos (Yamamura \& Kiritani, 1998, Turner, R., Song, Y. H., \& Uhm, K. B., 1999, Crozier \& Dwyer, 2006, Fraisse et al., 2006, Morin \& Thuiller, 2009, Maes et al., 2010). Sin embargo, se han realizado pocos intentos de estudiar los efectos del cambio climático sobre las plagas a nivel local en las zonas agrícolas y los cultivos de México. Los principales problemas del cambio climático pueden tener repercusiones en las plagas; por ejemplo, el aumento en las generaciones por temporada y la dispersión en las áreas geográficas (Patterson et al., 1999). Este conocimiento permitirá a los agricultores implementar algunas medidas de adaptación, como el uso de innovaciones técnicas, y de nuevas variedades y prácticas de manejo para superar los impactos del cambio climático (Parry et al., 1990). Esta investigación se centra en cuán probable es que las temperaturas más cálidas afecten al ciclo de vida del cogollero. Más específicamente, investigamos la forma en que los cambios en los regímenes de temperatura pueden repercutir en el número de generaciones por temporada. Planteamos la hipótesis de que, con un mayor número de días con temperaturas más cálidas en la temporada de cría, hay una mayor oportunidad de tener más generaciones por temporada. También presentamos como hipótesis que, con una mayor parte del día con temperaturas más cálidas en una temporada de cría, los ciclos de vida serán más cortos, permitiendo más generaciones por temporada, así como una mayor abundancia de plagas. También modelamos regiones en México que podrían ser climáticamente adecuadas para el cogollero y las superponemos a las zonas de cultivo de maíz para estudiar los posibles impactos en la producción. Los resultados de esta investigación 
the Instituto Nacional de Investigaciones Forestales, Agrícolas y Pecuarias (INIFAP) climate database. We combined both databases and created a single database for the years 1973 to 2009 . We used the single sine method in its canonical form (McMaster \& Wilhelm, 1997) to obtain the daily GDD. The formula is described below. The base temperature (Tbase) used for FAW to complete the life cycle was $10.9{ }^{\circ} \mathrm{C}$ (Ramirez, G. L., Bravo, M. H., \& Llanderal, C. C., 1987).

$G D D=\frac{\operatorname{Tmax}+\operatorname{Tmin}}{2}-$ Tbase

Where Tmax=maximum temperature of the day; Tmin=minimum temperature of the day.

The breeding season for FAW in the Mexican Plateau is from April to October (rain-fed and irrigated plots). The sum of GDD from April to October was obtained per year and the number of generations per year for FAW was calculated by the algebraic division of cumulative GDD per year with 599 heat units (GDD necessary to complete the life cycle of FAW) (Ramirez et al., 1987). Moving averages of periods of 20 years were calculated to determine the trends of GDD through the years of these five weather stations. Results were plotted to visualize trends and the Coefficient of Determination $\left(\mathrm{R}^{2}\right)$ as goodness-of-fit measure was estimated. podrían ayudar a comprender mejor cómo los cambios climáticos pueden impactar en las plagas del maíz, como el cogollero, y a implementar políticas de mitigación y adaptación para garantizar la producción de maíz y, por consiguiente, la seguridad alimentaria.

\section{Materiales y métodos}

\section{Área de estudio}

Los experimentos de modelación se llevaron a cabo para Zacatecas, México. El estado de Zacatecas se encuentra en el centro-norte de México, en la Meseta Central del país. Tiene una superficie de $75040 \mathrm{~km}^{2}$, y una altitud media de $2230 \mathrm{msnm}$. Su temperatura media anual es de $16{ }^{\circ} \mathrm{C}$ y su precipitación anual es de $510 \mathrm{~mm}$. Su territorio está situado entre los $25^{\circ} 09^{\prime}$ y $21^{\circ} 04^{\prime}$ de latitud norte y entre los $100^{\circ} 49^{\prime}$ y $104^{\circ} 19^{\prime}$ de longitud oeste (Figura 1).

\section{Análisis retrospectivo}

Se realizó un análisis retrospectivo para determinar el comportamiento de la acumulación de grados días de desarrollo (GDD) considerando los datos de cinco estaciones meteorológicas en el estado de Zacatecas. Las estaciones fueron la Colonia Gonzáles Ortega (1973-2009), El Chique (1973-2009), Tlaltenango

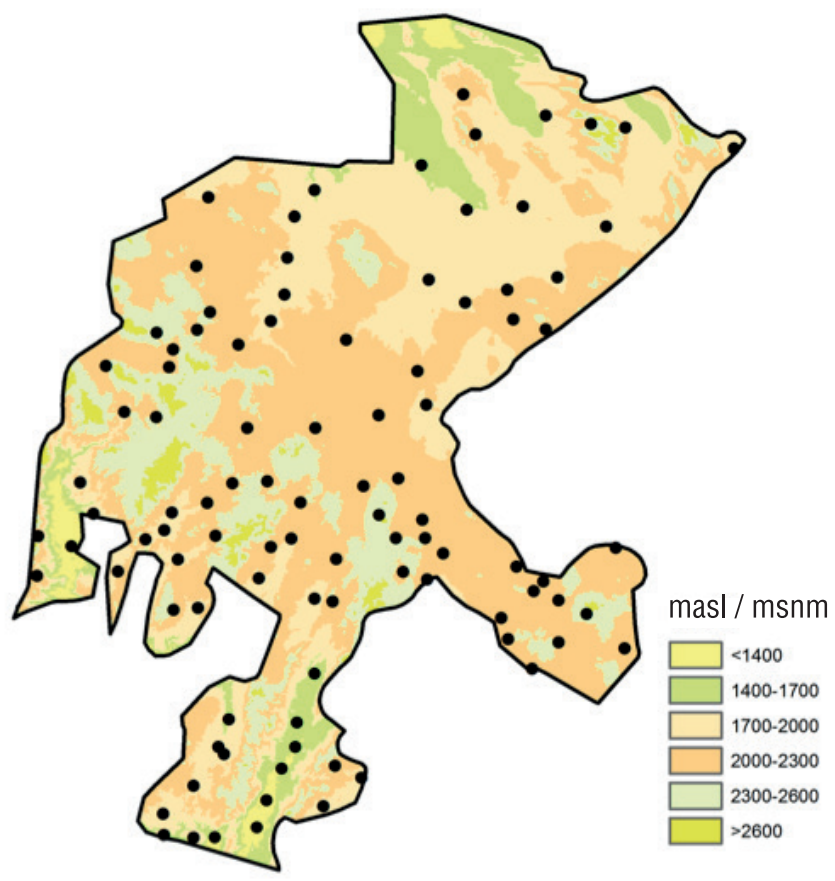

Figure 1. Spatial distribution of the 98 weather stations from the Comisión Nacional del Agua. The legend shows the altitude ranges in the Zacatecas state (Medina et al., 2003).

Figura 1. Distribución espacial de las 98 estaciones climatológicas de la Comisión Nacional del Agua. La escala muestra los rangos de altitud en el estado de Zacatecas (Medina et al., 2003). 


\section{Modeling}

Climate dataset: The next step was to develop a database of temperatures for the whole state of Zacatecas from the CNA meteorological network (98 weather stations). The CNA weather stations are located within the Zacatecas territory and cover the different climates of the state (Figure 1). Normal historical averages from 1961 to 2003 (available years depended on the weather station) of daily maximum and minimum temperatures for each month were estimated for every weather station (Medina \& Ruiz, 2004). Only data from CNA weather stations were used for this analysis. Since INIFAP meteorological network has only 36 weather stations and they started recording data in 2002, their climate data do not cover a large number of years for climate change analysis. Daily temperature data from the 98 weather stations of the CNA were used to estimate the cumulative GDD using the single sine method.

Monthly cumulative GDD data were calculated using the sum of daily GDD per month. The monthly cumulative GDD was added to the database of monthly temperature, as well as longitude, latitude and altitude of the weather stations. Regression models were developed using the Statistical Analysis System (SAS, 2002). For selecting the most significant variables the 'forward selection' technique was used. This method selects the best predictor where a natural hierarchy exists (Blanchet, F. G., Legendre, P., \& Borcard, D., 2008). The monthly GDD accumulated was considered the dependent variable in the equation.

GCM used: An ensemble of ten global circulation models (GCM) for Mexico based on the A2 scenario was used (Magaña \& Caetano, 2007). This scenario involves a highly heterogeneous world, with increasing population, regional economic development, economic growth and technological change slower and more fragmented that other scenarios. A temperature increase of $3.4{ }^{\circ} \mathrm{C}$ with a likely range of 2.0 to $5.4{ }^{\circ} \mathrm{C}$ is predicted by the end of the century for the A2 scenario (IPCC, 2007). The database of the mean temperature anomaly values of this model was used to estimate the climatic scenarios. The current climatic reference was taken from the Sistema de Información Ambiental Nacional (National Environmental Information System in English) of the INIFAP from 1961 to 2003 (Ruiz, C., Medina, G., Manríquez, O., \& Ramírez, D., 2010). The mean monthly temperatures were calculated for 2011 to 2060. After this, the monthly average maximum, average and minimum temperatures for the scenarios 2011 to 2020,2021 to 2030,2031 to 2040, 2041 to 2050 and 2051 to 2060 were estimated. Maps of the accumulated monthly GDD from all the scenarios were calculated with the monthly models
(1973-2009), Teúl de Gonzáles Ortega (1973-2007) y Campo Experimental Zacatecas, CEZac (1973-2010). Se utilizaron los datos de dos instituciones. Los datos climáticos de 1973 a 2002 se obtuvieron de la Comisión Nacional del Agua (CNA) y los de 2003 a 2009 de la base de datos climáticos del Instituto Nacional de Investigaciones Forestales, Agrícolas y Pecuarias (INIFAP). Se creó una única base de datos para los años 1973-2009. Utilizamos el método de seno simple en su forma canónica (McMaster \& Wilhelm, 1997) para obtener los GDD diarios. La fórmula se describe a continuación. La temperatura base (Tbase) utilizada para el gusano cogollero para completar el ciclo de vida fue de $10.9^{\circ} \mathrm{C}$ (Ramírez, G. L., Bravo, M. H., \& Llanderal, C. C., 1987).

$G D D=\frac{\operatorname{Tmax}+\operatorname{Tmin}}{2}-$ Tbase

Donde Tmax= temperatura máxima del día; Tmin= temperatura mínima del día.

La temporada de cría del gusano cogollero en el altiplano mexicano es de abril a octubre (parcelas de temporal y de riego). La suma de GDD de abril a octubre se obtuvo por año y el número de generaciones por año para el cogollero se calculó mediante la división algebraica de los GDD acumulados por año con 599 unidades calor (los GDD necesarios para completar el ciclo de vida del cogollero) (Ramírez et al., 1987). Se calcularon promedios móviles de periodos de 20 años para determinar las tendencias de los GDD a través de los años de estas cinco estaciones meteorológicas. Los resultados se graficaron para visualizar las tendencias y se estimó el Coeficiente de Determinación $\left(\mathrm{R}^{2}\right)$ como medida de bondad de ajuste.

\section{Modelación}

Conjunto de datos climáticos: El siguiente paso fue desarrollar una base de datos de temperaturas para todo el estado de Zacatecas a partir de la red meteorológica de la CNA (98 estaciones meteorológicas). Las estaciones de la CNA están ubicadas dentro del territorio de Zacatecas y cubren los diferentes climas del estado (Figura 1). Se estimaron los promedios históricos normales de 1961 a 2003 (los años disponibles dependieron de la estación meteorológica) de las temperaturas máximas y mínimas diarias de cada mes para cada estación meteorológica (Medina \& Ruíz, 2004). Para este análisis únicamente se utilizaron datos de las estaciones meteorológicas de la CNA. Dado que la red meteorológica del INIFAP solo tiene 36 estaciones que empezaron a registrar datos en 2002, los datos no abarcan un gran número de años para el análisis del cambio climático. Se utilizaron los datos de temperatura diaria de las 98 estaciones de la CNA para 
estimated with SAS (previous step) from April to October using the interpolation procedure in the IDRISI Geographic Information System (IDRISI GIS) software (Eastman, 2006). The number of generations of FAW was calculated with the algebraic division of the GDD accumulated images with 559 heat units, then generating the brood's maps for five scenarios besides the current map. Finally, the areas with the different numbers of generations from the diverse scenarios were calculated and the results were analysed.

\section{Results}

\section{Retrospective analysis}

The undertaken retrospective analysis using the moving average technique with periods of 20 years from 1973 to 2009 showed a trend of the cumulative GDD in each of the selected five weather stations (Figure 2). GDD per season tended to increase through the period. There are significant linear relationships considering the independent and dependent variables; the slopes of all the models are positive and different from zero. The estimated $\mathrm{R}^{2}$ value of each model is from 0.7 to 0.9 . estimar los GDD acumulados mediante el método de seno simple.

Los datos mensuales de GDD acumulados se calcularon utilizando la suma de los GDD diarios por mes. Los GDD acumulados mensualmente, se añadieron a la base de datos de la temperatura mensual, así como la longitud, latitud y altitud de las estaciones meteorológicas. Los modelos de regresión se desarrollaron utilizando el Statistical Analysis System (SAS, 2002). Para seleccionar las variables más significativas se utilizó la técnica de "selección directa". Este método selecciona el mejor predictor cuando existe una jerarquía natural (Blanchet, F. G., Legendre, P., \& Borcard, D., 2008). Los GDD mensuales acumulados se consideraron la variable dependiente en la ecuación.

MCG utilizado: se utilizó un conjunto de diez modelos de circulación global (MCG) para México basados en el escenario A2 (Magaña \& Caetano, 2007). Este escenario involucra un mundo altamente heterogéneo, con población creciente, desarrollo económico regional, crecimiento económico y cambio tecnológico más lento y fragmentado que otros escenarios. Se prevé

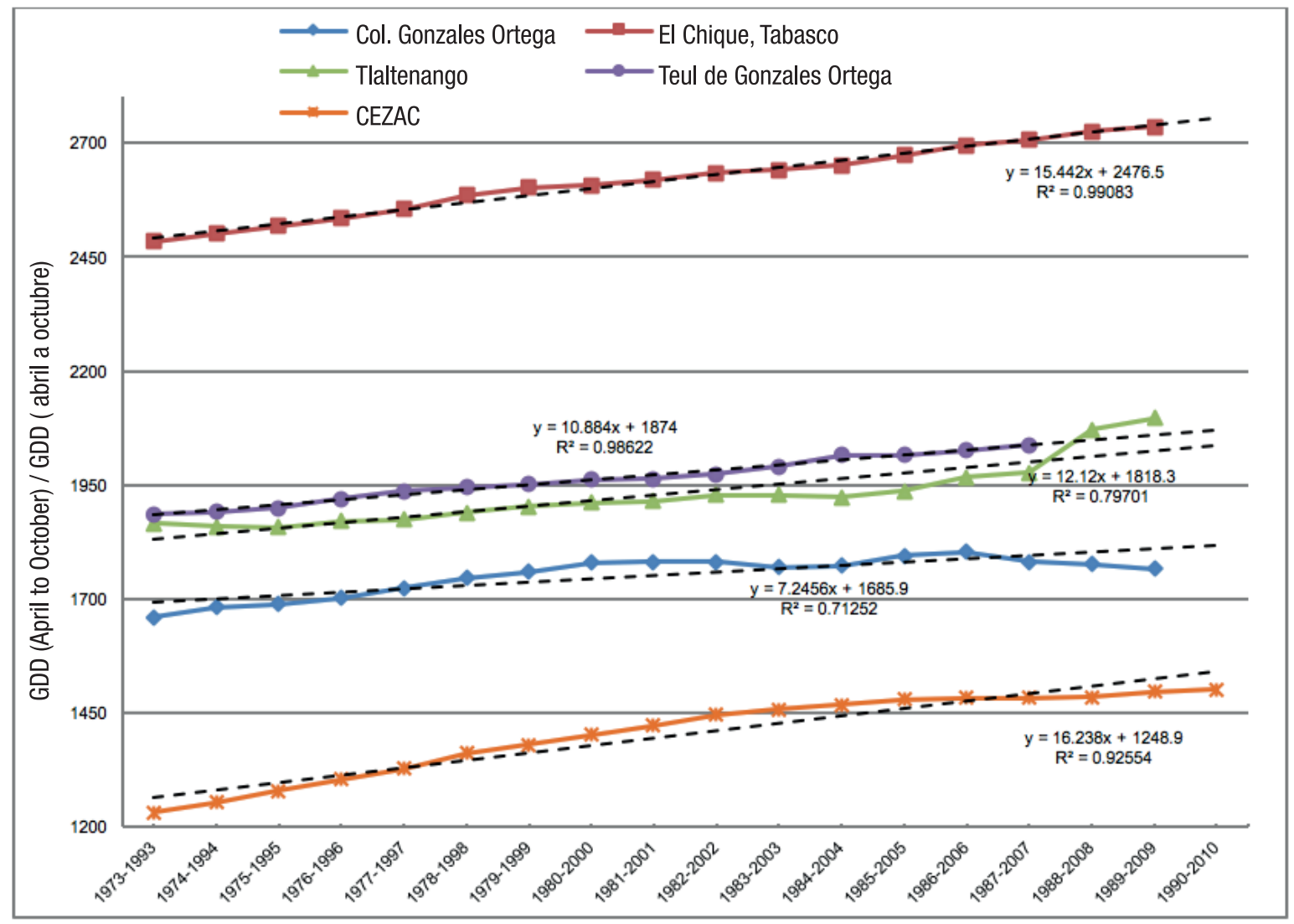

Figure 2. Linear trends of accumulated Growing Degree Days (from April to October) for five weather stations. GDD were estimated with the formula of the single sine method.

Figura 2. Tendencias lineales de los Grados Días de Desarrollo acumulados (de abril a octubre) para cinco estaciones meteorológicas. Los GDD se calcularon con la fórmula del método de seno simple. 
The regression models estimated with the normal historical averages (CNA) from 1961 to 2003 for the season covering April to October are presented in Table 1 . The average temperature was selected as the statistically significant independent variable. The resulting models were linear, with $\mathrm{R}^{2}$ values higher than 0.99 .

\section{Number of generations of FAW per season}

The models allowed us to generate maps with the number of generations per season under different climatic scenarios (Figure 3). Five maps were obtained for the climatic scenarios 2011 to 2020, 2021 to 2030, 2031 to 2040,2041 to 2050 , and 2051 to 2060 , as well as the current climatic scenario with baseline information from 1961-2003. These maps show an increase in the number of generations for the entire state. The areas under more pressure are the north and south west parts of Zacatecas territory. In the climatic scenarios, the areas with five generations increase as well as the areas with four generations. The areas with two and three generations decrease. A shift of the areas with three generations toward four generations occurs.

The number of hectares for all number of generations was obtained for the different scenarios. In the historical scenario are 22,000 ha with two generations; however, that area can become extinct by 2051-2060 (Table 2). The areas with two and three generations decrease under different climatic scenarios. In contrast, for the remaining number of generations, the areas increase under the different climatic scenarios. The four generations area does not suffer high changes in area. The areas accumulating the GDD necessary to complete five to seven generations per season increase. The areas with two FAW generations diminished dramatically and by $2051-2060$ there are un aumento de temperatura de $3.4{ }^{\circ} \mathrm{C}$, con un rango probable de 2.0 a $5.4{ }^{\circ} \mathrm{C}$, hacia fines de siglo para el escenario A2 (IPCC, 2007). La base de datos de los valores de anomalía de temperatura media de este modelo se utilizó para estimar los escenarios climáticos. La referencia climática actual se tomó del Sistema de Información Ambiental Nacional del INIFAP de 1961 a 2003 (Ruiz, C., Medina, G., Manríquez, O., \& Ramírez, D., 2010). Las temperaturas medias mensuales se calcularon para el periodo 2011-2060. Después de esto, se estimaron las temperaturas mensuales medias máximas, medias y mínimas para los escenarios 2011 a 2020, 2021 a 2030, 2031 a 2040, 2041 a 2050 y 2051 a 2060. Se elaboraron mapas de los GDD mensuales acumulados de todos los escenarios con los modelos mensuales estimados con SAS (paso anterior) de abril a octubre utilizando el procedimiento de interpolación del software del Sistema de Información Geográfica IDRISI (IDRISI SIG) (Eastman, 2006). El número de generaciones de cogollero se calculó con la división algebraica de las imágenes acumuladas de GDD con 559 unidades calor, generando después los mapas de las generaciones para cinco escenarios además del mapa actual. Finalmente, se calcularon las superficies con los diferentes números de generaciones de los diversos escenarios y se analizaron los resultados.

\section{Resultados}

\section{Análisis retrospectivo}

El análisis retrospectivo realizado mediante la técnica de promedios móviles con periodos de 20 años desde 1973 hasta 2009, mostró una tendencia de los GDD acumulados en cada estación meteorológica seleccionada (Figura 2). Los GDD por temporada tendieron a aumentar a lo largo del periodo. Existen relaciones lineales significativas considerando las

Table 1. Regression models of normal historical average. GDD is the dependent variable.

Cuadro 1. Modelos de regresión de los promedios históricos normales. Los GDD son la variable dependiente.

\begin{tabular}{cccc}
\hline Month/Mes & Intercept/Intercepto & Slope/Pendiente & $\mathbf{R}^{2}$ \\
\hline April/Abril & -319.65 & 6.96 & 0.9990 \\
May/Mayo & -335.16 & 11.74 & 0.9992 \\
June/Junio & -325.62 & 10.37 & 0.9997 \\
July/Julio & -338.15 & 31.01 & 0.9996 \\
August/Agosto & -338.98 & 31.05 & 0.9996 \\
September/Septiembre & -326.77 & 12.93 & 0.9997 \\
October/Octubre & -332.50 & 8.16 & 0.9993 \\
\hline
\end{tabular}



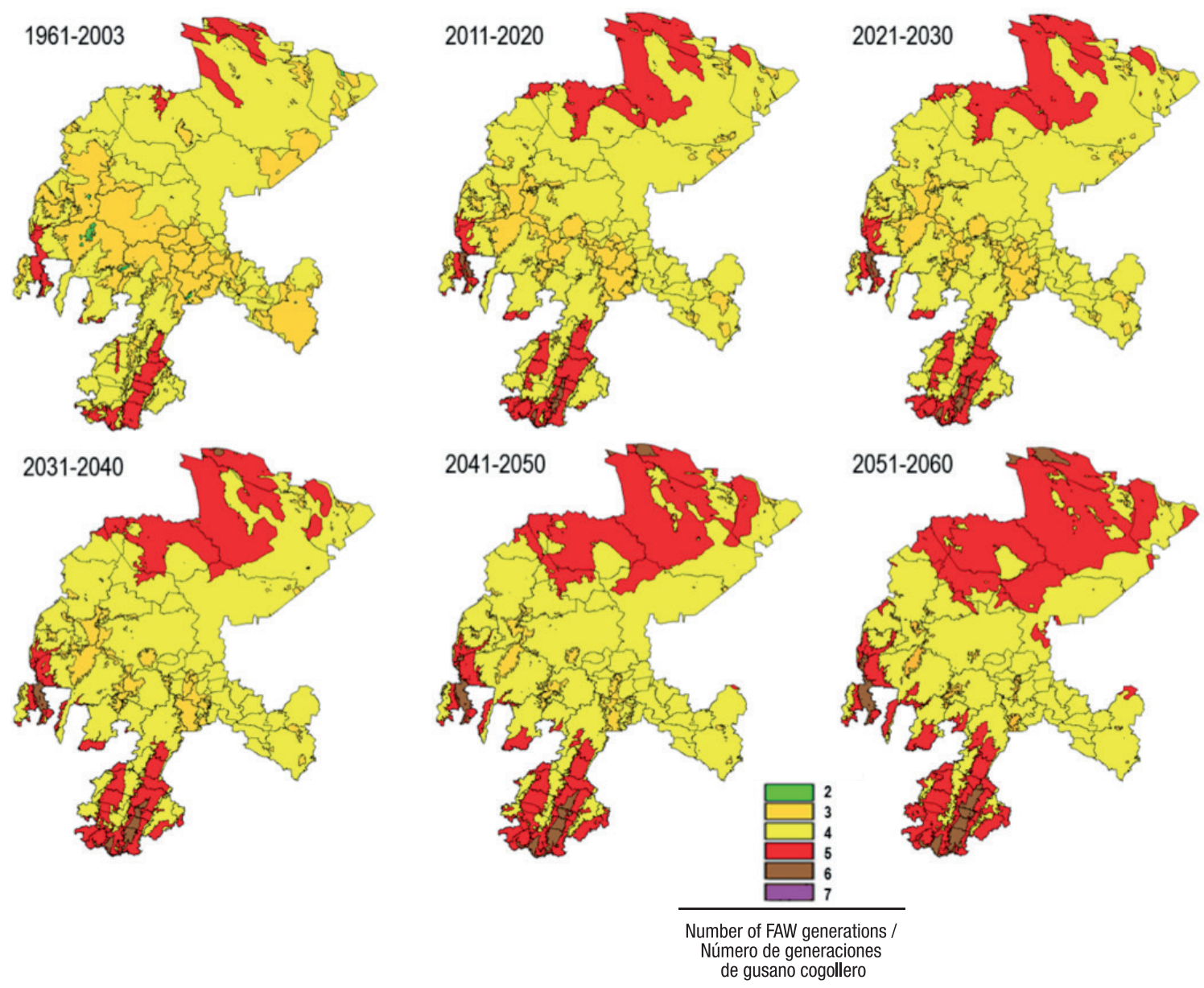

Figure 3. Number of fall armyworm generations per season (April to October) for the current climate and five climatic scenarios in Zacatecas, Mexico.

Figura 3. Número de generaciones de gusano cogollero por temporada (abril a octubre) para el clima actual y cinco escenarios climáticos en Zacatecas, México.

Table 2. Number of hectares under the current and climatic scenarios for the different number of generations of fall armyworm.

Cuadro 2. Número de hectáreas bajo el escenario actual y los escenarios climáticos para los diferentes números de generaciones de gusano cogollero.

\begin{tabular}{ccccccc}
\hline \multirow{2}{*}{$\begin{array}{c}\text { Number of } \\
\text { generations } \\
\text { Número de } \\
\text { generaciones }\end{array}$} & \multicolumn{5}{c}{$\begin{array}{c}\text { Area (Ha) for current climate and climatic scenarios/ } \\
\text { Superficie (ha) para el clima actual y los escenarios climáticos }\end{array}$} \\
\cline { 2 - 7 } & $\mathbf{1 9 6 1 - 2 0 0 3}$ & $\mathbf{2 0 1 1 - 2 0 2 0}$ & $\mathbf{2 0 2 1 - 2 0 3 0}$ & $\mathbf{2 0 3 1 - 2 0 4 0}$ & $\mathbf{2 0 4 1 - 2 0 5 0}$ & $\mathbf{2 0 5 1 - 2 0 6 0}$ \\
\hline 2 & 22,382 & 842 & 632 & 321 & 6 & 0 \\
3 & $2,320,799$ & 991,929 & 838,804 & 564,094 & 303,215 & 137,820 \\
4 & $4,624,047$ & $5,125,003$ & $5,119,009$ & $5,015,306$ & $4,690,969$ & $4,133,080$ \\
5 & 585,329 & $1,381,487$ & $1,525,091$ & $1,870,792$ & $2,398,838$ & $3,052,935$ \\
6 & 4,024 & 57,209 & 72,932 & 105,954 & 163,377 & 232,383 \\
7 & 0 & 0 & 0 & 0 & 62 & 253 \\
\hline
\end{tabular}


no more areas with two generations. The areas with three generations were $31 \%$ of the total state territory in the historical scenario case; however, it diminishes by $18 \%, 20 \%, 23 \%, 27 \%$ and $29 \%$ in the remaining scenarios. The areas with four generations remain almost similar during all the periods with variations of +|- $6.5 \%$ of area with respect to the historical scenario. The five generations area change is quite large with respect to the historical scenario, increasing from almost 600000 hectares to more than three million hectares in 2051-2060. The number of five generations shows a trend to expand to highest altitudes under the climatic scenarios (Figure 3). Even though the areas of six generations are insignificant in the historical scenario $(0.05 \%$ of total area), these areas can increase under the climatic scenarios and reach $3 \%$ of the total territory by 2051-2060. In the case of seven generations, no area is capable of accumulating the necessary GDD on the historical scenario; however, for the 2041-2050 scenario, a small area starts to show the conditions to accumulate more than 4,000 GDD per growing season (Table 2).

\section{Discussion}

Over the years, FAW has increased the number of generations in Zacatecas as the temperature has increased. We used the classic model of time series moving averages to review the GDD trends (Focardi \& Fabozzi, 2004). With this technique, each of the five weather stations time series shown a GDD increasing trend. Since insects have short life cycles, large scale mobility and high reproductive potential and physiological sensitivity to temperature even small changes in temperature may result in important changes in FAW abundance and distribution (Ayres \& Lombardero, 2000). The high values of $\mathrm{R}^{2}(0.7125$ to 0.9908 ) linked to the regression models appear to support our hypothesis that with higher number of days with higher temperatures in the breeding season there is an enhanced opportunity for more broods per season. This result demonstrates the possible strong relationship among warmer temperatures, the increase of cumulative GDD and the increase of insect generations (Yamamura \& Kiritani, 1998, Fuhrer, 2003, Diffenbaugh et al., 2008, Karuppaiah \& Sujayanad, 2012). However, higher temperatures $\left(37.8\right.$ to $\left.40{ }^{\circ} \mathrm{C}\right)$ could also be detrimental to FAW causing low survival rate or deformed adults (Barfield \& Jones, 1979, Simmons, 1993).

The climatic scenarios for FAW were modelled under the $\mathrm{A} 2$ scenario. The A2 scenario projects an increase of best estimate of $3.4^{\circ} \mathrm{C}$ by the period 2090-2099, with a likely range of 2.0 to $5.4{ }^{\circ} \mathrm{C}$ (IPCC, 2007). A $2{ }^{\circ} \mathrm{C}$ increase in the mean temperature for some insects, such as Neophilaenus lineatus, can extend their range and their variables independientes y dependientes; las pendientes de todos los modelos son positivas y diferentes de cero. El valor estimado de $\mathrm{R}^{2}$ de cada modelo es de 0.7 a 0.9 .

En el Cuadro 1 se presentan los modelos de regresión estimados con los promedios históricos normales (CNA) de 1961 a 2003, para la temporada que abarca de abril a octubre. La temperatura media fue seleccionada como la variable independiente estadísticamente significativa. Los modelos resultantes fueron lineales, con valores de $\mathrm{R}^{2}$ superiores a 0.99 .

\section{Número de generaciones de gusano cogollero por temporada}

Los modelos nos permitieron generar mapas con el número de generaciones por temporada en diferentes escenarios climáticos (Figura 3). Se obtuvieron cinco mapas para los escenarios climáticos 2011 a 2020, 2021 a 2030, 2031 a 2040, 2041 a 2050 y 2051 a 2060, así como el escenario climático actual con información de referencia de 1961 a 2003. Estos mapas muestran un aumento en el número de generaciones para todo el estado. Las áreas bajo mayor presión son las partes norte y suroeste del territorio zacatecano. En los escenarios climáticos, las superficies con cinco generaciones aumentan, así como las de cuatro generaciones. Las superficies con dos y tres generaciones disminuyen. Se produce un desplazamiento desde las superficies con tres generaciones hacia las de cuatro generaciones.

Se obtuvo el número de hectáreas de todas las generaciones para los diferentes escenarios. En el escenario histórico son 22000 ha con dos generaciones; sin embargo, esa superficie puede extinguirse entre 2051 y 2060 (Cuadro 2). Las superficies con dos y tres generaciones disminuyen en los diferentes escenarios climáticos. En cambio, para el resto de las generaciones, las superficies aumentan bajo los diferentes escenarios climáticos. Las cuatro generaciones no sufren grandes cambios de superficie. Las superficies que acumulan los GDD necesarios para completar de cinco a siete generaciones por temporada aumentan. Las zonas con dos generaciones de cogollero disminuyeron drásticamente y para 2051-2060 ya no existen zonas con dos generaciones. Las superficies con tres generaciones fueron $31 \%$ del total del territorio estatal en el caso del escenario histórico; sin embargo, disminuyen a 18, 20, 23,27 y $29 \%$ en los escenarios restantes. Las superficies con cuatro generaciones permanecen casi similares durante todos los periodos, con variaciones de $+/-6.5 \%$ de área con respecto del escenario histórico. El cambio del área de cinco generaciones es drástico con respecto al escenario histórico, aumentando de casi 600000 hectáreas a más de tres millones de hectáreas en 20512060. El número de cinco generaciones muestra una tendencia a expandirse a mayores altitudes en los 
life cycle will decrease from 3 to 2 weeks (Whittaker \& Tribe, 1996). The projected maps show that the life cycle of FAW can be reduced through the years due to higher accumulation of GDD, and FAW might be able to accomplish a higher number of generations per season. Besides, moths of four different families of butterflies and moths from the same order that FAW belong to have shown an extra generation after 1980 in Central Europe (Altermatt, 2010). These results imply that days with higher temperatures in a breeding season might decrease the life cycle period, enabling more broods per season as well as a higher number of pests.

An important increase in area with more FAW generations was observed (Table 2 and Figure 3). FAW is a migrant moth from the order Lepidoptera, and it is known that migrant species may respond better and faster to the phenomenon of weather change (Porter, J., Parry, M., \& Carter, T., 1991, Sparks, T. H., Dennis, R. L., Croxton, P. J., Cade, M., 2007). These species might be able to invade new regions where hosts do not have defence mechanisms against these pests. For example, by the end of the century an increase of $3{ }^{\circ} \mathrm{C}$ in mean annual temperature may permit corn to spread to north of UK and, as a consequence, Ostrinia nubilalis (a pest of grain, particularly maize) may move to the north up to $1220 \mathrm{~km}$ (Porter et al., 1991). The success of this migration could depend on the ability of 0 . nubilalis, as well as on weather conditions such as direction of winds and weather fronts (Porter et al., 1991). Similarly, the success of FAW spreading to other areas can depend on other factor besides the favourable warmer temperatures. The increase of pest in amount and diversity at places with high and medium altitudes has been recorded in butterflies (Bale et al., 2002). Areas of five generations of FAW under various climatic scenarios also show a possible expansion toward higher altitudes. It must be noted that butterflies and FAW belong to the same order.

Bale et al. (2002) mentioned that if the host availability is limited there can be no change toward increase in the number of generations (voltinism). Other results have shown that the synchrony on host plant and insects may limit the range of a potential plague in host exploitation and the plant tissues used by insects (Dewar \& Watt, 1992; van Asch \& Visser, 2007). In addition, some insects are specialized to feed from specific plant tissues and if those are not available then the survival of the insect is compromised. If crop and pest temperature change move toward different directions, the process could suffer a lack of synchronization (Cannon, 1998). However, evolution has shown that selection processes could synchronize again during pest-crop interaction (Watt, A., Ward, L., \& Eversham, B., 1990). Accuracy on the host phenological synchrony is required in many escenarios climáticos (Figura 3). Aunque las superficies de seis generaciones son insignificantes en el escenario histórico (0.05 \% de la superficie total), estas áreas pueden aumentar bajo los escenarios climáticos y alcanzar el 3 \% del territorio total hacia 2051-2060. En el caso de siete generaciones, ninguna zona es capaz de acumular los GDD necesarios en el escenario histórico; sin embargo, para el escenario 2041-2050, una zona pequeña comienza a mostrar las condiciones para acumular más de 4000 GDD por temporada de cría (Cuadro 2).

\section{Discusión}

A lo largo de los años, el gusano cogollero ha aumentado el número de generaciones en Zacatecas a medida que la temperatura ha ido aumentando. Utilizamos el modelo clásico de promedios móviles de series de tiempo para revisar las tendencias de los GDD (Focardi \& Fabozzi, 2004). Con esta técnica, cada una de las series temporales de las cinco estaciones meteorológicas presentó una tendencia creciente de los GDD. Dado que los insectos tienen ciclos de vida cortos, movilidad a gran escala y elevados potencial reproductivo y sensibilidad fisiológica a la temperatura, incluso pequeños cambios de temperatura pueden dar lugar a importantes cambios en la abundancia y distribución del cogollero (Ayres \& Lombardero, 2000). Los altos valores de $\mathrm{R}^{2}(0.7125$ a 0.9908$)$ vinculados a los modelos de regresión parecen sustentar nuestra hipótesis en cuanto a que con un mayor número de días con temperaturas más altas en la temporada de cría hay una mayor oportunidad de tener más generaciones por temporada. Este resultado demuestra la posible fuerte relación entre las temperaturas más cálidas, el aumento de los GDD acumulados y el aumento de las generaciones de insectos (Yamamura \& Kiritani, 1998, Fuhrer, 2003, Diffenbaugh et al., 2008, Karuppaiah \& Sujayanad, 2012). Sin embargo, las temperaturas más altas $\left(37.8\right.$ a $\left.40{ }^{\circ} \mathrm{C}\right)$ también podrían ser perjudiciales para el cogollero causando una baja tasa de supervivencia o adultos deformes (Barfield \& Jones, 1979, Simmons, 1993).

Los escenarios climáticos para el gusano cogollero fueron modelados bajo el escenario A2. El escenario A2 contempla un aumento estimado de $3.4{ }^{\circ} \mathrm{C}$ para el periodo 2090-2099, con un rango probable de 2.0 a $5.4^{\circ} \mathrm{C}$ (IPCC, 2007). Un aumento de $2^{\circ} \mathrm{C}$ en la temperatura media de algunos insectos, como Neophilaenus lineatus, puede ampliar su rango y su ciclo de vida disminuirá de 3 a 2 semanas (Whittaker \& Tribe, 1996). Los mapas proyectados muestran que el ciclo de vida del gusano cogollero puede reducirse a lo largo de los años debido a una mayor acumulación de GDD, y los cogolleros podrían ser capaces de lograr un mayor número de generaciones por temporada. Además, las polillas 
insects to secure their food. This is not the case for FAW because it is a polyphagous insect and does not depend on an exclusive host for the survival; the synchrony with host phenology could not be a restriction. Besides, FAW can feed on different tissues of corn and is not dependent on a particular corn tissue. Summing up, the lack of synchrony will not be a limitation for the expansion and increment of FAW.

Multivotine species would have more generations with increasing temperatures and faster rates of development, leading to shorter development times. The corn earworm (Heliothis zea) is expected to increase the number of generations in the Upper Grain Belt regions of North America (Porter et al., 1991). In Finland, plagues of cereal crops are likely to add an extra generation (Porter et al., 1991). In horticultural crops in New Zealand, Cydia pomonella and Panonychus ulmi may have additional generations (Porter et al., 1991). Important corn plagues like corn earworm (Helicoverpa zea), european corn borer (Ostrinia nubilalis), northern corn rootworm (Diabrotica barberi) and western corn rootworm (D. virgifera virgifera) may expand their ranges in agricultural areas of the western United States of America due to the increase of atmospheric greenhouse gases (1961-1989 current climate and 20712099 A2 scenario) (Diffenbaugh et al., 2008). Our results show that FAW can have more generations per season and expand their range in the future. As a consequence, pest management will be more problematic. This analysis is based just on temperature. Insects and hosts have complex interactions and parameters that are not included in our study. Our modelling results show a shift in the number of generations; however, there are other factors that will influence the outbreak of FAW on corn production.

\section{Conclusion}

Insects can adapt to increases in temperature. As a consequence of warmer seasons, they could spend more time on the crops, survive winter, have a faster development and reach phenological stages faster and that could cause more damage and more stress to the crop, leading to lower productivity. Our results show that the number of generations can increase under various climatic scenarios. Areas with two generations can turn to three generations, three generations to four generations and so on. The spatial area does not can suffer shifts of more than one generation over the next 50 years; however, the areas of risk can increase. An increase in the number of generations of FAW can generate more pest pressure on agricultural areas with negative economic and social impacts on the food supply. Under these situations, applying more agrochemical products and new measures to control FAW damage could be necessary. The results of this de cuatro familias diferentes de mariposas y polillas del mismo orden al que pertenece el cogollero han mostrado una generación adicional después de 1980, en Europa Central (Altermatt, 2010). Estos resultados implican que los días con temperaturas más altas en una temporada de cría podrían disminuir el periodo del ciclo de vida, permitiendo más generaciones por temporada, así como un mayor número de plagas.

Se observó un importante aumento en la superficie con más generaciones de cogollero (Cuadro 2 y Figura 3). El gusano cogollero es una polilla migratoria del orden Lepidoptera, y es sabido que las especies migratorias pueden responder mejor y más rápido al fenómeno del cambio climático (Porter, J., Parry, M., \& Carter, T., 1991, Sparks, T. H., Dennis, R. L., Croxton, P. J., \& Cade, M., 2007). Estas especies podrían ser capaces de invadir nuevas regiones en las que los hospederos no cuenten con mecanismos de defensa contra estas plagas. Por ejemplo, para finales de siglo, un aumento de $3{ }^{\circ} \mathrm{C}$ en la temperatura media anual puede permitir que el maíz se extienda hacia el norte del Reino Unido $\mathrm{y}$, como consecuencia, la Ostrinia nubilalis (una plaga de los cereales, particularmente del maíz) podría desplazarse hacia el norte hasta $1220 \mathrm{~km}$ (Porter et al., 1991). El éxito de esta migración podría depender de la capacidad de la 0 . nubilalis, así como de condiciones meteorológicas tales como la dirección de los vientos y los frentes meteorológicos (Porter et al., 1991). De forma similar, el éxito de la propagación del cogollero hacia otras zonas puede depender de otros factores además de las temperaturas favorables más cálidas. Incrementos en la cantidad y la diversidad de plagas en lugares de altitudes alta y media han sido registrados entre mariposas (Bale et al., 2002). Las zonas de cinco generaciones de cogollero bajo diversos escenarios climáticos también muestran una posible expansión hacia altitudes mayores. Debe tenerse en cuenta que las mariposas y el cogollero pertenecen al mismo orden.

Bale et al. (2002) mencionaron que si la disponibilidad de hospederos es limitada no puede haber cambios hacia el aumento del número de generaciones (voltinismo). Otros resultados han demostrado que la sincronía entre la planta hospedera y los insectos puede limitar el alcance de una plaga potencial en la explotación del hospedero y los tejidos de la planta utilizados por los insectos (Dewar \& Watt, 1992; van Asch \& Visser, 2007). Además, algunos insectos están especializados en alimentarse de tejidos específicos de las plantas y si estos no están disponibles, la supervivencia del insecto se ve comprometida. Si los cambios de temperatura de los cultivos y las plagas se desplazan en direcciones diferentes, el proceso podría sufrir una falta de sincronización (Cannon, 1998). Sin embargo, la evolución ha demostrado que los procesos de selección podrían volver a sincronizarse durante la interacción 
modelling could be used to generate mitigation and adaptation policies to guarantee food production. This analysis is based on air temperature only; however, insects and hosts have complex interactions; then, other factors not included in our study having also influence on the outbreak of FAW should be involved in future works through the climatic scenarios approach.

End of English version

\section{References / Referencias}

Altermatt, F. (2010). Climatic warming increases voltinism in European butterflies and moths. Proceedings of the Royal Society B: Biological Sciences 277, 1281-1287.

Ayres, M. P., \& Lombardero, M. J. (2000). Assessing the consequences of global change for forest disturbance from herbivores and pathogens. Sci. Total Environ. 262, 263-286.

Baker, A., \& Zahniser, S. (2006). Ethanol reshapes the corn market. Amber Waves 4, 30-35.

Bale, J. S., Masters, G. J., Hodkinson, I. D., Awmack, C., Bezemer, T. M.,..., Whittaker, J. (2002). Herbivory in global climate change research: direct effects of rising temperature on insect herbivores. Global Change Biol. 8, 1-16.

Barfield, C., \& Jones, J. (1979). Research needs for modeling pest management systems involving defoliators in agronomic crop systems. Fla. Entomol., 98-114.

Blanchet, F. G., Legendre, P., \& Borcard, D., (2008). Forward selection of explanatory variables. Ecology 89, 26232632.

Bradshaw, W. E., \& Holzapfel, C. M. (2006). Evolutionary response to rapid climate change. Science 312, 14771478.

Brown, W. L., Zuber, M. S., Darrah, L. L., \& Glover, D. V. (1985). Origin, adaptation and types of corn. In: Creech, R.G., Fleming, A.A., Schertz, K.F., Troyer, A.F. (Eds.), National Corn Handbook. Iowa State University, Ames Iowa.

Cannon, R. J. (1998). The implications of predicted climate change for insect pests in the UK, with emphasis on non-indigenous species. Global Change Biol. 4, 785796.

Casmuz, A., Juárez, M. L., Socías, M. G., Murúa, M. G., Prieto, S., Medina, S.,..., Gastaminza, G. (2010). Revisión de los hospederos del gusano cogollero del maíz, Spodoptera frugiperda (Lepidoptera: Noctuidae). Rev. Soc. Entomol. Argent. 69, 209-231.

Coope, G. (1970). Interpretations of Quaternary Insect Fossils. Annu. Rev. Entomol. 15, 97-121.

Crozier, L., \& Dwyer, G. (2006). Combining populationdynamic and ecophysiological models to predict climate-induced insect range shifts. The American Naturalist 167, 853-866. plaga-cultivo (Watt, A., Ward, L., \& Eversham, B., 1990). La precisión en la sincronía fenológica del hospedero es necesaria en muchos insectos para asegurar su alimento. Este no es el caso del gusano cogollero porque es un insecto polífago y no depende de un hospedero exclusivo para su supervivencia; la sincronía con la fenología del hospedero podría no ser una restricción. Además, el cogollero puede alimentarse de diferentes tejidos del maíz y no depende de un tejido en particular. En resumen, la falta de sincronía no será una limitación para la expansión y el incremento del gusano cogollero.

Las especies multivoltinas tendrían más generaciones con las temperaturas en aumento, así como tasas de desarrollo más rápidas, lo cual daría lugar a periodos de desarrollo más cortos. Se prevé que el gusano elotero (Heliothis zea) aumente el número de generaciones en las Regiones Altas del Cinturón de Cereales de América del Norte (Porter et al., 1991). En Finlandia, es probable que las plagas de los cultivos de cereales añadan una generación adicional (Porter et al., 1991). En los cultivos hortícolas de Nueva Zelanda, Cydia pomonella y Panonychus ulmi podrían tener generaciones adicionales (Porter et al., 1991). Importantes plagas del maíz como el gusano elotero (Helicoverpa zea), el barrenador europeo del maíz (Ostrinia nubilalis), el gusano de la raíz del maíz del norte (Diabrotica barberi) y el gusano de la raíz del maíz del oeste $(D$. virgifera virgifera) podrían ampliar sus áreas de distribución en las zonas agrícolas del oeste de los Estados Unidos de América debido al aumento de los gases de efecto invernadero en la atmósfera (clima actual 1961-1989 y 2071-2099 escenario A2) (Diffenbaugh et al., 2008). Nuestros resultados muestran que el cogollero puede tener más generaciones por temporada y ampliar su área de distribución en el futuro. Como consecuencia, el manejo de plagas será más problemático. Este análisis se basa únicamente en la temperatura. Los insectos y los hospederos tienen interacciones y parámetros complejos que no se incluyen en nuestro estudio. Los resultados de nuestros modelos muestran un cambio en el número de generaciones; sin embargo, existen otros factores que influirán en el brote de gusano cogollero en la producción de maíz.

\section{Conclusión}

Los insectos pueden adaptarse a los aumentos en la temperatura. Como consecuencia de estaciones más cálidas, podrían pasar más tiempo en los cultivos, sobrevivir al invierno, tener un desarrollo más acelerado y alcanzar las etapas fenológicas más rápidamente, y ello podría causar más daño y más estrés al cultivo, lo que llevaría a una menor productividad. Nuestros resultados muestran que el número de generaciones puede aumentar bajo varios escenarios climáticos. 
Dewar, R., \& Watt, A. (1992). Predicted changes in the synchrony of larval emergence and budburst under climatic warming. Oecologia 89, 557-559.

Diffenbaugh, N. S., Krupke, C. H., White, M. A., \& Alexander, C. E. (2008). Global warming presents new challenges for maize pest management. Environmental Research Letters 3, 044007.

Eastman, J. (2006). IDRISI v 15.1. IDRISI Andes. Guide to GIS and image processing 1 .

FAO. (1992). Maize in human nutrition. http://www.fao.org/ docrep/t0395e/T0395E00.htm\#Contents.

FAOSTAT, F. (2014). Agriculture Organization of the United Nations. Statistical database, http://faostat3.fao.org/ home/E.

Focardi, S. M., \& Fabozzi, F. J. (2004). The mathematics of financial modeling and investment management. John Wiley \& Sons, Hoboken, New Jersey.

Fraisse, C., Breuer, N., Zierden, D., Bellow, J., Paz, J., Cabrera, V.,..., Hoogenboom, G. (2006). AgClimate: A climate forecast information system for agricultural risk management in the southeastern USA. Comput. Electron. Agric. 53, 13-27.

Fuhrer, J. (2003). Agroecosystem responses to combinations of elevated $\mathrm{CO}_{2}$, ozone, and global climate change. Agric., Ecosyst. Environ. 97, 1-20.

García, N. G., \& Tarango, R. S. H. (2009). Manejo biorracional del gusano cogollero en maíz. Centro de Investigacion Regional Norte Centro, Campo Experimental Delicias.

Hernández, J. L. M., López, E. C. B., Garza, E. G., \& Mayek, N. P. (2008). Spatial distribution of Spodoptera frugiperda (Lepidoptera: Noctuidae) in maize landraces grown in Colima, México. Int. J. Trop. Insect Sci. 28, 126-129.

IPCC. (2007). Climate Change 2007: The Physical Science Basis. Contribution of Working Group I to the Fourth Assessment Report of the Intergovernmental Panel on Climate Change. In: Solomon, S., Qin, D., Manning, M., Chen, Z., Marquis, M., Averyt, K., Tignor, M.M., Miller, H.L. (Eds.). Cambridge University Press, Cambridge, p. 996.

IPCC. (2014). Climate Change 2014: Impacts, Adaptation, and Vulnerability. Part A: Global and Sectoral Aspects. Contribution of Working Group II to the Fifth Assessment Report of the Intergovernmental Panel on Climate Change. In: Field, C.B., Barros, V.R., Dokken, D.J., Mach, K.J., Mastrandrea, M.D., Bilir, T.E., Chatterjee, M., Ebi, K.L., Estrada, Y.O., Genova, R.C., Girma, B., Kissel, E.S., Levy, A.N., MacCracken, S., Mastrandrea, P.R., White, L.L. (Eds.), Cambridge, United Kingdom and New York, NY, USA,, p. 1132.

Karuppaiah, V., \& Sujayanad, G. (2012). Impact of climate change on population dynamics of insect pests. World Journal of Agricultural Sciences 8, 240-246.

Maes, D., Titeux, N., Hortal, J., Anselin, A., Decleer, K., De Knijf, G.,..., Luoto, M. (2010). Predicted insect diversity declines under climate change in an already impoverished region. J. Insect Conserv. 14, 485-498.

Magaña, V., \& Caetano, E. (2007). Pronóstico climático estacional regionalizado para la República Mexicana
Las zonas con dos generaciones pueden pasar a tres generaciones, tres generaciones a cuatro generaciones, y así sucesivamente. El área espacial no puede sufrir desplazamientos de más de una generación en los próximos 50 años, sin embargo, las áreas de riesgo pueden aumentar. Un aumento del número de generaciones de gusano cogollero puede generar una mayor presión de plagas en las zonas agrícolas con repercusiones económicas y sociales negativas en el suministro de alimentos. En tales situaciones, podría ser necesario aplicar más productos agroquímicos y nuevas medidas para controlar los daños causados por el gusano cogollero. Los resultados de esta modelación podrían utilizarse para generar políticas de mitigación y adaptación que garanticen la producción de alimentos. Este análisis se basa únicamente en la temperatura del aire; sin embargo, los insectos y los hospederos tienen interacciones complejas; por consiguiente, otros factores no incluidos en nuestro estudio, también podrían influir en el brote de cogollero, deberían incluirse en estudios futuros mediante el enfoque de los escenarios climáticos.

Fin de la version en español

como elemento para la reducción de riesgo, para la identificación de opciones de adaptación al cambio climático y para la alimentación del sistema: cambio climático por estado y por sector. Dirección General de Investigación sobre Cambio Climático, SEMARNATINE. SEMARNAT-INE.

McMaster, G. S., \& Wilhelm, W. (1997). Growing degree-days: one equation, two interpretations. Agricultural and Forest Meteorology 87, 291-300.

Medina, G. G., Cabañas, B. C., Ruiz Corral, J. A., Madero, J. T., Rubio, S. D., Rumayor, A. R.,..., Bravo, A. L. (2003). Potencial productivo de especies agrícolas en el estado de Zacatecas. INIFAP, Centro de Investigación Regional Norte Centro, Campo Experimental Zacatecas, Mexico.

Medina, G. G., Ruíz, C. J. A., Ramírez, L. M. R., \& Díaz, P. G. (2011). Efecto del cambio climático en la acumulación de frío en la región manzanera de Chihuahua. Revista Mexicana de Ciencias Agrícolas 2, 251-263.

Medina, G. G., \& Ruiz, J.A. C. (2004). Estadísticas climatológicas básicas del estado de Zacatecas (Período 1961-2003). INIFAP, Centro de Investigacion Regional Norte Centro, Campo Experimental Zacatecas.

Morin, X., \& Thuiller, W.(2009). Comparing niche-and processbased models to reduce prediction uncertainty in species range shifts under climate change. Ecology 90, 1301-1313.

O’Day, M. H., Becker, A., Keaster, A. J., Kabrick, L. R., \& Steffey, K. L. (1998). Corn insect pests: A diagnostic guide. MU Extension, University of Missouri Columbia. 
Parry, M., Porter, J., \& Carter, T. (1990). Agriculture: climatic change and its implications. Trends Ecol. Evol. 5, 318322.

Patterson, D., Westbrook, J., Joyce, R., Lingren, P., \& Rogasik, J. (1999). Weeds, insects, and diseases. Clim. Change 43, 711-727.

Pollard, E., Moss, D., \& Yates, T. (1995). Population trends of common British butterflies at monitored sites. J. Appl. Ecol., 9-16.

Porter, J., Parry, M., \& Carter, T. (1991). The potential effects of climatic change on agricultural insect pests. Agricultural and Forest Meteorology 57, 221-240.

Ramirez, G. L., Bravo, M. H., \& Llanderal, C. C. (1987). Desarrollo de Spodoptera frugiperda (J.E. Smith) (lepidoptera: Noctuidae) bajo diferentes condiciones de temperatura y humedad. Agrociencia 67, 161-171.

Randall, M. G. M. (1986). The predation of predispersed Juncus squarrosus seeds by Coleophora alticolella (Lepidoptera) larvae over a range of altitudes in northern England. Oecologia 69, 460-465.

Rosenzweig, C., Iglesias, A., Yang, X., Epstein, P. R., \& Chivian, E. (2001). Climate change and extreme weather events; implications for food production, plant diseases, and pests. Global Change Hum. Health 2, 90-104.

Ruiz, C., Medina, G., Manríquez, O., \& Ramírez, D. (2010). Evaluación de la vulnerabilidad y propuestas de medidas de adaptación a nivel regional de algunos cultivos básicos y frutales ante escenarios de cambio climático. Informe final proyecto INIFAP-INE. Guadalajara, Jalisco, México.

Ruiz, C. J. A., Sánchez, G. J. d J., Hernández, C. J. M., Willcox, M. C., Ramírez, O. G.,..., González, E. D. R., (2013). Identificación de razas mexicanas de maíz adaptadas a condiciones deficientes de humedad mediante datos biogeográficos. Revista Mexicana de Ciencias Agrícolas 4, 829-842.

SAS. (2002). User Guide. Statistical Analysis System. Inc. Cary, NC.

Saunders, D. S. (2002). Insect clocks. Elsevier.

Simmons, A. M. (1993). Effects of constant and fluctuating temperatures and humidities on the survival of
Spodoptera frugiperda pupae (Lepidoptera: Noctuidae). Fla. Entomol., 333-340.

Sparks, A. N. (1979). A review of the biology of the Fall Armyworm. The Florida Entomologist 62, 82-87.

Sparks, T. H., Dennis, R. L., Croxton, P. J., \& Cade, M. (2007). Increased migration of Lepidoptera linked to climate change. Eur. J. Entomol. 104, 139-143.

Suárez, R. F., Chávez, L. A. M., \& Mariscal, A. G. (2013). Importancia de los maíces nativos de México en la dieta nacional. Una revisión indispensable. Revista Fitotecnia Mexicana 36, 275-283.

Tauber, M. J., Tauber, C. A., \& Shinzo, M. (1986). Seasonal Adaptations of Insects. Oxford University Press.

Turner, R., Song, Y. H., \& Uhm, K. B. (1999). Numerical model simulations of brown planthopper Nilaparvata lugens and white-backed planthopper Sogatella furcifera (Hemiptera: Delphacidae) migration. Bull. Entomol. Res. 89, 557-568.

Valdez, T. J. B., Soto, L. F., Osuna, E. T., \& Báez, S. M. A. (2012). Modelos de predicción fenológica para maíz blanco (Zea mays L.) y gusano cogollero (Spodoptera frugiperda JE Smith). Agrociencia 46, 399-410.

Valdivieso, L., \& Núñez, E. (1984). Plagas del maíz y sus enemigos naturales. INIPA, CICIU, IICA.

van Asch, M., \& Visser, M. E. (2007). Phenology of forest caterpillars and their host trees: the importance of synchrony. Annu. Rev. Entomol. 52, 37-55.

Vickery, R. A. (1929). Studies on the fall army worm in the Gulf Coast district of Texas. United States Department of Agriculture, Economic Research Service, p. 63.

Watt, A., Ward, L., \& Eversham, B. (1990). The greenhouse effect and terrestrial ecosystems of the UK. Invertebrates. HMSO Publication Centre.

Whittaker, J. B., \& Tribe, N. (1996). An altitudinal transect as an indicator of responses of a spittlebug (Auchenorrhynchaz cercopidae) to climate change. Eur. J. Entomol. 93, 319-324.

Yamamura, K., \& Kiritani, K. (1998). A simple method to estimate the potential increase in the number of generations under global warming in temperate zones. Appl. Entomol. Zool. 33, 289-298. 